J. Agric. Res. \& Dev. 14(1)1-12. Copy@ 2015. Faculty of Agriculture, University of Ilorin. Nigeria

\title{
RESPONSE OF LEAF NUTRIENT CONTENT, GROWTH AND CORM YIELD OF COCOYAM (Xanthosoma sagittifolium Schott) TO TILLAGE AND POULTRY MANURE
}

\author{
A.O. ADEKIYA ${ }^{1 *}$, S. O. OJENIYI ${ }^{2}$, AND T. M. AGBEDE ${ }^{3}$ \\ ${ }^{1}$ Deparpment of Crop and Soil Sciences, Landmark University, P.M.B. 1001,Omu-Aran, Kwara State, \\ ${ }^{2}$ Department of Crop, Soil and Pest Management, Federal University of Technonology, P.M.B. 704, Akure, \\ Ondo State, ${ }^{3}$ Department of Agricultural Technology, Rufus Giwa Polytechnic, P.M.B. 1019, Owo, Ondo \\ State, Nigeria. " adekiya2009@yahoo.com; +2348034813715 http://dx.doi.org/10.4314/jard.v14i1.1
}

\begin{abstract}
In order to provide information on soil management requirement of cocoyam, three field experiments were carried out at two locations in 2007, 2008 and 2009 on an Alfisol at Owo southwest Nigeria to evaluate the effects of different tillage methods and poultry manure levels on leaf nutrient content, growth and corm yield of cocoyam. The treatments were five tillage methods: manual clearing $(M C)$, manual ridging $(M R)$, manual mounding $(M M)$, ploughing plus harrowing $(P+H)$ and ploughing plus harrowing twice $(P+2 H)$ and five poultry manure (PM) levels: 0.0, 2.5, 5.0, 7.5 and $10.0 \mathrm{t} / \mathrm{ha}$ ). These were factorially combined and arranged in a randomized complete block design and replicated three times. In 2008, P+H had highest leaf N, P, K Ca and Mg, but in 2009, MC had the highest while $P+2 H$ had the least. In the first 2 years (2007 \& 2008), MR, MM and P+H increased cocoyam growth and corm yield compared with MC, but in 2009, MC had highest growth and yield of cocoyam and $\mathrm{P}+2 \mathrm{H}$ had the least. Irrespective of tillage method, leaf $\mathrm{K}, \mathrm{Ca}$, $M g$, plant height, leaf area and corm yield of cocoyam only increased up to $7.5 \mathrm{t} / \mathrm{ha} P M$, although leaf $N$ and $P$ increased up to 10.0 t/ha PM. The mean data for the 3 years showed that $P+H+7.5 P M$ had highest corm yield $(10.2 \mathrm{t} / \mathrm{ha})$ while unmanured $P+2 \mathrm{H}$ had the least (6.1 t/ha). Relative to $P+2 H$, the $P+H+7.5 P M$ increased corm yield by $69 \%$. In order to maximise performance of cocoyam, a combination of $P+H+7.5 \mathrm{t} / \mathrm{ha} P M$ is recommended
\end{abstract}

Keywords: Tillage, poultry manure, leaf nutrient content, cocoyam, corm

\section{INTRODUCTION}

Cocoyam (Xanthosoma sagittifolium) is a tuber crop produced mainly in Africa (60\%) and Asia (40\%), with minor quantities in the Caribbean and Oceania (FAO, 1991). It is cultivated for human nutrition and cash income to the farmers. As food for human consumption, the nutritional value of the various parts of cocoyam is primarily caloric (Davies et al., 2008). The underground corm and cormel provide easily digested starch and the leaves are nutritious spinach-like vegetable which gave a lot of mineral, vitamin and thiamine (Sefa-Dedeh and Kofi-Agyir, 2002). Cocoyams have $1.12 \%$ and $1.55 \%$ protein for taro and tannia, respectively, which is higher than most other tropical root crops (Kay, 1987). It contains $20-28 \%$ starch and the starch is more digestible than other starch crops (Bradbury, 1988; Onayemi and Nwigwe, 1987). Cocoyam has the potential of putting an end to food insecurity in Nigeria. 
However, the average global yield is only $6 \mathrm{t} / \mathrm{ha}$ (Onwueme, 1991). Due to physical and chemical limitations of the soil in tropical Africa, cocoyam cannot attain its potential yield and benefits. Cocoyam requires fertile soils for optimum performance and yield and these soils are declining in Nigeria. There is, therefore, a compelling need to study soil conditions conducive to cocoyam production. These soil conditions may be influenced by tillage and manuring.

Tillage operations are known to influence soil nutrients conservation and release. This information for cocoyam is hitherto lacking in southwest Nigeria as there have not been researches comparing the traditional tillage methods with mechanised tillage as it affects cocoyam production. Few studies carried out in Nigeria and other tropical countries produced inconclusive and controversial results under different tillage practices compared (Hulugalle et al., 1985). Moreso, tillage studies in Nigeria on cocoyam are concentrated on Ultisol of southeast Nigeria (Ndaeyo et al., 2003; Hulugalle et al., 1985).

Organic manure (in form of poultry manure) is known to be effective in the maintenance of adequate supply of organic matter into the soil and enhanced crop performance (Adekiya and Agbede, 2009). The effect of different organic manures especially poultry manure on the actual yield of cocoyam had not been properly documented. Information on this is necessary because farmers rarely use chemical fertilizers due to its scarcity and high cost. There is therefore the need to develop affordable and sustainable soil management package for cocoyam production. This could be the integration of tillage with poultry manure. Studies on the relative effect of tillage cum poultry manure applications on soil properties and cocoyam yield is scarce. Nyakatawa et al. (2001) has reported that it is possible to increase yield of crops on degraded soils by using organic manure for soil fertility improvement after adopting appropriate tillage method. This study is to assess the impact of tillage and poultry manure on the leaf nutrient concentration, growth and corm yield of cocoyam on an Alfisol of southwest Nigeria is expected to provide information on soil management requirement of cocoyam.

\section{MATERIALS AND METHODS}

\section{Site Description}

Field experiments were conducted at two locations (sites A and B) at Owo, Ondo state, Nigeria in 2007, 2008 and 2009 cropping seasons. Owo is located on latitude $7^{0} 12^{\prime} \mathrm{N}$, longitude $5^{0} 32^{\prime} \mathrm{E}$ within the forest-savanna transition zone of southwest Nigeria. The soil at Owo belongs to the broad group Alfisol classified as Oxic Tropludalf or Luvisol (FAO, 1998).

\section{Field Experiment and treatments}

The experiment each year consisted of $5 \times 5$ factorial combinations of five tillage methods: manual clearing $(\mathrm{MC})$, manual ridging $(\mathrm{MR})$, manual mounding $(\mathrm{MM})$, ploughing plus harrowing $(\mathrm{P}+\mathrm{H})$ and ploughing plus harrowing twice $(\mathrm{P}+2 \mathrm{H})$ and five poultry manure levels: 0 , 2.5, 5.0, 7.5 and $10.0 \mathrm{t} / \mathrm{ha}$. The 25 treatments were arranged in a randomized complete block design and replicated three times. The treatments compared at the two locations were:(a) manual clearing only (MCO): manual clearing with cutlass and weeds removed from the plots before planting without application of poultry manure, (b) manual clearing with application of $2.5 \mathrm{t} / \mathrm{ha}$ poultry manure $(\mathrm{MC}+2.5 \mathrm{PM})$, (c) manual clearing with application of $5.0 \mathrm{t} / \mathrm{ha}$ poultry manure $(\mathrm{MC}+5.0 \mathrm{PM}),(\mathrm{d})$ 


\section{Growth and Corm Yield of Cocoyam}

manual clearing with application of $7.5 \mathrm{t} / \mathrm{ha}$ poultry manure (MC+7.5 PM), (e) manual clearing with application of 10.0 t/ha poultry manure $(\mathrm{MC}+10.0 \mathrm{PM})$, (f) manual ridging only (MRO): manual ridge construction with hoe after manual clearing with cutlass and weeds removed from the plots without application of poultry manure, (g) manual ridging with application of $2.5 \mathrm{t} / \mathrm{ha}$ poultry manure $(\mathrm{MR}+2.5 \mathrm{PM})$, (h) manual ridging with application of $5.0 \mathrm{t} / \mathrm{ha}$ poultry manure $(\mathrm{MR}+5.0 \mathrm{PM})$, (i) manual ridging with application of $7.5 \mathrm{t} / \mathrm{ha}$ poultry manure $(\mathrm{MR}+7.5 \mathrm{PM}),(\mathrm{j})$ manual ridging with application of 10.0 t/ha poultry manure $(\mathrm{MR}+10.0 \mathrm{PM}),(\mathrm{k})$ manual mounding only (MMO): manual mound construction with hoe after manual clearing with cutlass and weeds removed from plots without application of poultry manure, (l) manual mounding with application of $2.5 \mathrm{t} / \mathrm{ha}$ poultry manure $(\mathrm{MM}+2.5 \mathrm{PM}),(\mathrm{m})$ manual mounding with application of $5.0 \mathrm{t} / \mathrm{ha}$ poultry manure $(\mathrm{MM}+5.0 \mathrm{PM})$, (n) manual mounding with application of $7.5 \mathrm{t} / \mathrm{ha}$ poultry manure $(\mathrm{MM}+7.5 \mathrm{PM})$, (o) manual mounding with application of $10.0 \mathrm{t} / \mathrm{ha}$ poultry manure $(\mathrm{MM}+10.0 \mathrm{PM})$, (p) ploughing plus harrowing only $(\mathrm{P}+\mathrm{HO})$ : ploughing to $15 \mathrm{~cm}$ soil depth with a tractor mounted disc plough followed by harrowing with a tractor mounted disc harrow without application of poultry manure, (q) ploughing plus harrowing with application of $2.5 \mathrm{t} /$ ha poultry manure $(\mathrm{P}+\mathrm{H}+2.5 \mathrm{PM})$, (r) ploughing plus harrowing with application of $5.0 \mathrm{t} / \mathrm{ha}$ poultry manure $(\mathrm{P}+\mathrm{H}+5.0 \mathrm{PM})$, (s) ploughing plus harrowing with application of $7.5 \mathrm{t} / \mathrm{ha}$ poultry manure $(\mathrm{P}+\mathrm{H}+7.5 \mathrm{PM})$, (t) ploughing plus harrowing with application of 10.0 t/ha poultry manure $(\mathrm{P}+\mathrm{H}+10.0 \mathrm{PM})$, (u) ploughing plus harrowing twice only $(\mathrm{P}+2 \mathrm{HO})$; ploughing to $15 \mathrm{~cm}$ soil depth with a tractor mounted disc plough followed by two passes of harrow with tractor mounted disc harrow without application of poultry manure, (v) ploughing plus harrowing twice with application of $2.5 \mathrm{t} / \mathrm{h}$ a poultry manure $(\mathrm{P}+2 \mathrm{H}+2.5 \mathrm{PM})$, (w) ploughing plus harrowing twice with application of $5.0 \mathrm{t} /$ ha poultry manure $(\mathrm{P}+2 \mathrm{H}+5.0 \mathrm{PM})$, (x) ploughing plus harrowing twice with application of $7.5 \mathrm{t} /$ ha poultry manure $(\mathrm{P}+2 \mathrm{H}+7.5 \mathrm{PM})$ and $(\mathrm{y})$ ploughing plus harrowing twice with application of $10.0 \mathrm{t} / \mathrm{ha}$ poultry manure $(\mathrm{P}+2 \mathrm{H}+10.0 \mathrm{PM})$.

\section{Crop establishment}

The experimental plot size in each trial was $12 \mathrm{~m}$ x $10 \mathrm{~m}$. Tillage treatments were carried out in April each year. Cocoyam (Xanthosoma sagittifolium cv. Owo local) cormels weighing about $150 \mathrm{~g}$ were planted. One cocoyam cormel was planted per hole at a spacing of $1 \mathrm{~m} \mathrm{x} 1 \mathrm{~m}$ which gave a plant population of 10,000 plants/ha. Poultry manure was applied 3 weeks after planting by ring method at the rate of $0.0,2.5,5.0,7.5$, and $10.0 \mathrm{t} / \mathrm{ha}$. Weeding was done manually twice at 45 and 110 days after planting. The same treatment method was used on each plot for the 3 years of the experiment.

\section{Soil sampling and analysis}

Prior to the commencement of the experiment in 2007, soil samples were taken from 0 to $15 \mathrm{~cm}$ depths of a pit located at each site. The samples were put in an oven set at $100^{\circ} \mathrm{C}$ for $24 \mathrm{~h}$ for determination of bulk density. Total porosity was calculated from bulk density using particle density of $2.65 \mathrm{~g} / \mathrm{cm}^{3}$. The soil samples were also bulked, air-dried and sieved using a $2 \mathrm{~mm}$ sieve and analysed for particle size, soil organic matter, total $\mathrm{N}, \mathrm{P}, \mathrm{K}, \mathrm{Ca}, \mathrm{Mg}$ and $\mathrm{pH}$. Samples were analysed as described by Carter (1993). Particle size analysis was done using hydrometer method (Sheldrick and Hand Wang, 1993). The organic matter was determined by the procedure of Walkley and Black using the 
dichromate wet oxidation method (Nelson and Sommer, 1996). Total $\mathrm{N}$ was determined by micro-Kjeldahl digestion method (Bremner, 1996), available P was determined by Bray-1 extraction followed by molybdenum blue colorimetry (Frank et al., 1998). Exchangeable K, Ca and $\mathrm{Mg}$ were extracted using ammonium acetate, $\mathrm{K}$ level was determined using a flame photometer, and $\mathrm{Ca}$ and $\mathrm{Mg}$ by the EDTA titration method.

\section{Leaf analysis}

In 2008 and 2009, 2 to 3 week old cocoyam leaves were collected at 168 days after planting from five plants per plot for chemical analyses (Hulugalle et al., 1985). Leaf samples were oven dried for $24 \mathrm{~h}$ at $70^{\circ} \mathrm{C}$ and ground in a Willey-mill. Leaf $\mathrm{N}$ was determined by micro-Kjeldahl digestion method. Samples were dry- ashed at $500^{\circ} \mathrm{C}$ for $6 \mathrm{~h}$ in a furnace and extracted using nitricperchloric-sulphuric acid mixture for determination of $\mathrm{P}, \mathrm{K}, \mathrm{Ca}$, and $\mathrm{Mg}$ (Tel and Hagarty, 1984). Leaf $P$ was determined using vanadomolybdatecolorimetry method, $K$ was determined by the EDTA titration method (AOAC, 1997).

\section{Determination of growth and yield parameters}

Ten plants were selected per plot for determination of plant height and leaf area at 168 days after planting when the cocoyam plant reached its peak growth (Ndon et al., 2003). Plant height was measured by meter rule and leaf area by graphical method (Ndon et al., 2003). The corm yield was determined by harvesting ten cocoyam plants per plot and weighing on a top loading balance to determine their fresh weights

\section{Statistical analysis}

Data collected from each experiment were subjected to analysis of variance (ANOVA), using SPSS 15.0 and Microsoft Office Excel 2007 packages, and treatment means were compared using the Duncan's multiple range test (DMRT) at $\mathrm{p}=0.05$ probability level.

\section{RESULTS AND DISCUSSION}

\section{Soil physical and chemical properties before experimentation}

The data in Table 1 show the result of the two sites before experimentation in 2007. The soils at both sites were sandyloam in texture. The soils were generally low in essential nutrients except $\mathrm{Mg}$ which was adequate (Akinrinde and Obigbesan, 2000). The bulk density of the two sites was also high.

\section{Effect of tillage methods on leaf nutrient concentration of cocoyam}

Table 2 shows the effect of tillage methods on the leaf nutrient concentration of cocoyam in 2008 and 2009 cropping seasons. In 2008, P+H and MC had the highest and least values of N, P, K, $\mathrm{Ca}$ and $\mathrm{Mg}$ respectively. The order was $\mathrm{P}+\mathrm{H}>\mathrm{MM}>\mathrm{MR}>\mathrm{P}+2 \mathrm{H}>\mathrm{MC}$. In 2009, the nutrients tended to reduce with tillage. Leaf $\mathrm{N}, \mathrm{P}, \mathrm{K}, \mathrm{Ca}$ and $\mathrm{Mg}$ reduced in the order $\mathrm{MC}>\mathrm{MR}>\mathrm{MM}>$ $\mathrm{P}+\mathrm{H}>\mathrm{P}+2 \mathrm{H}$. The mean values for the two years indicate similar values for MC, MR, MM and $\mathrm{P}+\mathrm{H}$, but $\mathrm{P}+2 \mathrm{H}$ had clearly the least $\mathrm{N}, \mathrm{P}, \mathrm{K}, \mathrm{Ca}$ and $\mathrm{Mg}$ content. 


\section{Growth and Corm Yield of Cocoyam}

Table 1. Soil Physical and Chemical Properties of sites before experimentation in 2007

\begin{tabular}{lll}
\hline Parameter & Site A & Site B \\
\hline Sand $(\mathrm{g} / \mathrm{kg})$ & 682 & 627 \\
Silt $(\mathrm{g} / \mathrm{kg})$ & 160 & 142 \\
Clay $(\mathrm{g} / \mathrm{kg})$ & 158 & 231 \\
Textural class & Sandyloam & Sandyloam \\
Bulk density $\left(\mathrm{Mg} / \mathrm{m}^{3}\right)$ & 1.55 & 1.54 \\
Total porosity $(\%)$ & 41.4 & 41.9 \\
$\mathrm{pH}($ water$)$ & 5.58 & 5.72 \\
Organic matter $(\%)$ & 2.97 & 2.90 \\
Total N $(\%)$ & 0.18 & 0.19 \\
Available P $(\mathrm{mg} / \mathrm{kg})$ & 4.5 & 5.0 \\
Exchangeable K $(\mathrm{cmol} / \mathrm{kg})$ & 0.15 & 0.13 \\
Exchangeable Ca(cmol/ $/ \mathrm{kg})$ & 1.78 & 2.39 \\
Exchangeable $\mathrm{Mg}(\mathrm{cmol} / \mathrm{kg})$ & 0.81 & 1.03 \\
\hline
\end{tabular}

Table 2. Mean values of Leaf Nutrient Concentration of Cocoyam at site A and B as affected by different Tillage Methods

\begin{tabular}{llllllllllll}
\hline & \multicolumn{2}{c}{$\mathrm{N}(\%)$} & \multicolumn{2}{c}{$\mathrm{P}(\%)$} & \multicolumn{2}{c}{$\mathrm{K}(\%)$} & \multicolumn{2}{c}{$\mathrm{Ca}(\%)$} & \multicolumn{2}{c}{$\mathrm{Mg}(\%)$} \\
$\begin{array}{l}\text { Tillage } \\
\text { methods }\end{array}$ & 2008 & 2009 & 2008 & 2009 & 2008 & 2009 & 2008 & 2009 & 2008 & 2009 \\
\hline MC & $1.90 \mathrm{~cd}$ & $2.30 \mathrm{a}$ & $0.32 \mathrm{c}$ & $0.39 \mathrm{a}$ & $0.27 \mathrm{~d}$ & $0.34 \mathrm{a}$ & $0.40 \mathrm{c}$ & $0.56 \mathrm{a}$ & $0.19 \mathrm{c}$ & $0.23 \mathrm{a}$ \\
$\mathrm{MR}$ & $2.14 \mathrm{~b}$ & $2.03 \mathrm{~b}$ & $0.40 \mathrm{~b}$ & $0.33 \mathrm{~b}$ & $0.32 \mathrm{~b}$ & $0.29 \mathrm{~b}$ & $0.46 \mathrm{~b}$ & $0.43 \mathrm{~b}$ & $0.22 \mathrm{~b}$ & $0.19 \mathrm{~b}$ \\
$\mathrm{MM}$ & $2.16 \mathrm{~b}$ & $2.03 \mathrm{~b}$ & $0.39 \mathrm{~b}$ & $0.33 \mathrm{~b}$ & $0.31 \mathrm{~b}$ & $0.28 \mathrm{~b}$ & $0.46 \mathrm{~b}$ & $0.43 \mathrm{~b}$ & $0.22 \mathrm{~b}$ & $0.19 \mathrm{~b}$ \\
$\mathrm{P}+\mathrm{H}$ & $2.40 \mathrm{a}$ & $1.80 \mathrm{c}$ & $0.46 \mathrm{a}$ & $0.28 \mathrm{c}$ & $0.37 \mathrm{a}$ & $0.22 \mathrm{c}$ & $0.55 \mathrm{a}$ & $0.40 \mathrm{c}$ & $0.26 \mathrm{a}$ & $0.16 \mathrm{c}$ \\
$\mathrm{P}+2 \mathrm{H}$ & 1.75 & $1.65 \mathrm{~d}$ & $0.30 \mathrm{~d}$ & $0.24 \mathrm{~d}$ & $0.26 \mathrm{~d}$ & $0.18 \mathrm{~d}$ & $0.36 \mathrm{~d}$ & $0.35 \mathrm{~d}$ & $0.18 \mathrm{~d}$ & $0.14 \mathrm{~d}$ \\
\hline
\end{tabular}

Values followed by similar letters under the same column are not significantly different at $p=0.05$ according to Duncan's multiple range test (DMRT); MC: manual clearing; MR:manual ridging; MM: manual mounding; $\mathrm{P}+\mathrm{H}$ : ploughing + harrowing; $\mathrm{P}+2 \mathrm{H}$ : ploughing +2 harrowing.

\section{Effect of poultry manure on leaf nutrient concentration of cocoyam}

The effect of poultry manure on the leaf nutrient concentration of cocoyam in 2008 and 2009 cropping seasons are shown in Table 3. Irrespective of tillage method employed, leaf $\mathrm{N}$ and $\mathrm{P}$ concentrations increased with level of manure up to $10 \mathrm{t} / \mathrm{ha}$ in 2008 and 2009 at both sites of study. Leaf $\mathrm{K}, \mathrm{Ca}$, and $\mathrm{Mg}$ tended to increase up to $7.5 \mathrm{t} / \mathrm{ha}$ manure. This could be due to nutrient imbalance after the $7.5 \mathrm{t} / \mathrm{ha}$ poultry manure. Manure application in excess of crop requirement can cause a significant build-up of $\mathrm{N}$ and $\mathrm{P}$ (Eghball, 2002) which can cause nutrient imbalance and thereby prevent uptake of certain nutrients (Obi and Akinsola, 1995). 
Adekiya, O.A. et al

Table 3. Mean values of Leaf Nutrient Concentration of Cocoyam at site A and B as affected by different Poultry Manure Levels.

\begin{tabular}{lccccccccccc}
\hline & \multicolumn{1}{c}{$\mathrm{N}(\%)$} & \multicolumn{2}{c}{$\mathrm{P}(\%)$} & \multicolumn{2}{c}{$\mathrm{K}(\%)$} & \multicolumn{2}{c}{$\mathrm{Ca}(\%)$} & \multicolumn{2}{c}{$\mathrm{Mg}(\%)$} \\
Poultry & 2008 & 2009 & 2008 & 2009 & 2008 & 2009 & 2008 & 2009 & 2008 & 2009 \\
manure & & & & & & & & & & \\
\hline $0.0 \mathrm{PM}$ & $2.07 \mathrm{e}$ & $1.99 \mathrm{e}$ & $0.37 \mathrm{e}$ & $0.31 \mathrm{e}$ & $0.30 \mathrm{~d}$ & $0.27 \mathrm{~d}$ & $0.44 \mathrm{~d}$ & $0.43 \mathrm{~d}$ & $0.21 \mathrm{~d}$ & $0.19 \mathrm{~d}$ \\
$2.5 \mathrm{PM}$ & $2.30 \mathrm{~d}$ & $2.22 \mathrm{~d}$ & $0.42 \mathrm{~d}$ & $0.36 \mathrm{~d}$ & $0.34 \mathrm{c}$ & $0.31 \mathrm{c}$ & $0 / 50 \mathrm{~b}$ & $0.48 \mathrm{c}$ & $0.23 \mathrm{c}$ & $0.22 \mathrm{c}$ \\
$5.0 \mathrm{PM}$ & $2.64 \mathrm{c}$ & $2.53 \mathrm{c}$ & $0.46 \mathrm{c}$ & $0.41 \mathrm{c}$ & $0.39 \mathrm{~b}$ & $0.35 \mathrm{~b}$ & $0.55 \mathrm{~b}$ & $0.54 \mathrm{~b}$ & $0.27 \mathrm{~b}$ & $0.27 \mathrm{~b}$ \\
$7.5 \mathrm{PM}$ & $2.93 \mathrm{~b}$ & $2.84 \mathrm{~b}$ & $0.51 \mathrm{~b}$ & $0.48 \mathrm{~b}$ & $0.45 \mathrm{a}$ & $0.42 \mathrm{a}$ & $0.61 \mathrm{a}$ & $0.62 \mathrm{a}$ & $0.32 \mathrm{a}$ & $0.31 \mathrm{a}$ \\
$10.0 \mathrm{PM}$ & $3.36 \mathrm{a}$ & $3.13 \mathrm{a}$ & $0.58 \mathrm{a}$ & $0.54 \mathrm{~d}$ & $0.33 \mathrm{c}$ & $0.32 \mathrm{c}$ & $0.46 \mathrm{~cd}$ & $0.50 \mathrm{~cd}$ & $0.22 \mathrm{~cd}$ & $0.23 \mathrm{c}$ \\
\hline
\end{tabular}

Values followed by similar letters under the same column are not significantly different at $p=0.05$ according to Duncan's multiple range test (DMRT); PM: poultry manure.

\section{Effect of tillage methods on the growth and corm yield of cocoyam}

Results of the effect of different tillage methods on plant height, leaf area and corm yield of cocoyam are shown respectively in Figures 1, 2 and 3. In the first two years (2007 and 2008), reduced and conventional tillage increased plant height, leaf area and corm yield relative to MC. However in the third year (2009) MC had the highest value of plant height, leaf area and corm yield relative to $\mathrm{MR}, \mathrm{MM}, \mathrm{P}+\mathrm{H}$ and $\mathrm{P}+2 \mathrm{H}$. This implies that in the third year continuous tillage might have reduced soil quality and nutrient availability leading to reduced plant growth and yield. It could be observed that in 2009, MC had highest values of leaf N, P, K and Ca compared with $\mathrm{MR}, \mathrm{MM}, \mathrm{P}+\mathrm{H}$ and $\mathrm{P}+2 \mathrm{H}$. Hence the most intensive and repetitive tillage $\mathrm{P}+2 \mathrm{H}$ consistently had least values of leaf N, P, K, Ca and Mg in 2008 and 2009 at both sites of study.

The mean data for the two sites and three years showed that $\mathrm{MC}, \mathrm{MR}, \mathrm{MM}, \mathrm{P}+\mathrm{H}$ and $\mathrm{P}+2 \mathrm{H}$ had values of 54,58,57, 63 and 49 respectively for plant height; leaf area values per plant were 119, $140,138,157$ and $113 \mathrm{~cm}^{2}$ and values for corm yield per hectare were 6.5, 7.0, 6.9, 7.4 and 6.1 $\mathrm{t} / \mathrm{ha}$. Therefore, non - tillage $(\mathrm{MC})$ and intensive tillage $(\mathrm{P}+2 \mathrm{H})$, with triple passes of implement lowered crop performance relative to reduced tillage (MR, MM) and conventional tillage $(\mathrm{P}+\mathrm{H})$, with conventional tillage giving the highest mean plant height, leaf area and corm yield for the three years of study. Reduced tillage methods (MR, MM) clearly gave higher cocoyam growth and yield compared with $\mathrm{MC}$ and $\mathrm{P}+2 \mathrm{H}$. This could be due to their more compact soil and associated high bulk density (Adekiya and Ojeniyi, 2011) which reduced root growth and nutrient uptake especially in 2009 in case of $\mathrm{P}+2 \mathrm{H}$ (Table 2). Also soil density is known to limit tuber growth in crops such as cassava, yam and sweet potato (Agbede and Ojeniyi, 2003; Agbede and Adekiya, 2009; Agbede, 2008).

Mechanised tillage involving three passes of implement compact the soil and reduces porosity (Adekiya and Ojeniyi, 2011). The moderate and manual tillage methods such as MM, MR and $\mathrm{P}+\mathrm{H}$ is therefore recommended for cocoyam especially on initially compact soil with bulk density not less than $1.55 \mathrm{~g} / \mathrm{cm}^{3}$ (Adekiya, 2014). The physical 


\section{Growth and Corm Yield of Cocoyam}

and chemical properties of the sandy loam soils showed a high bulk density of 1.55 and 1.54 $\mathrm{g} / \mathrm{cm}^{3}$ for sites A and B. Hence moderate/minimal tillage is required for enhanced corm and plant growth.

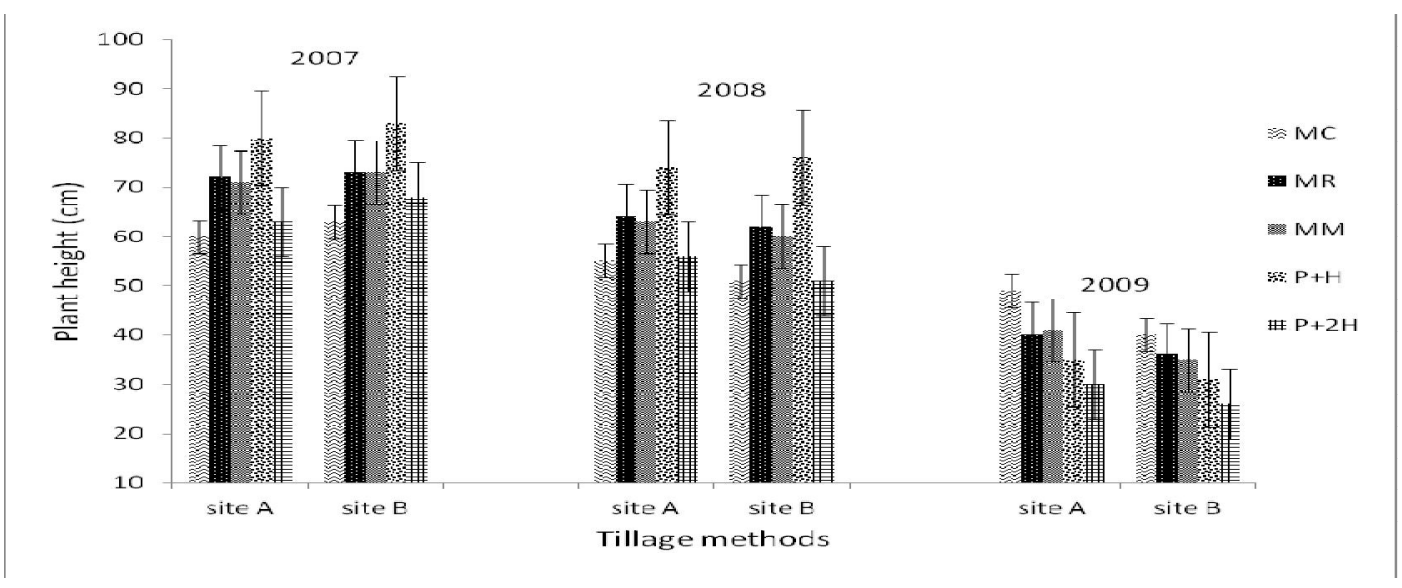

Figure 1: Effect of tillage methods on cocoyam plant height in 2007, 2008 and 2009. Vertical bars show standard errors of paired comparisons.

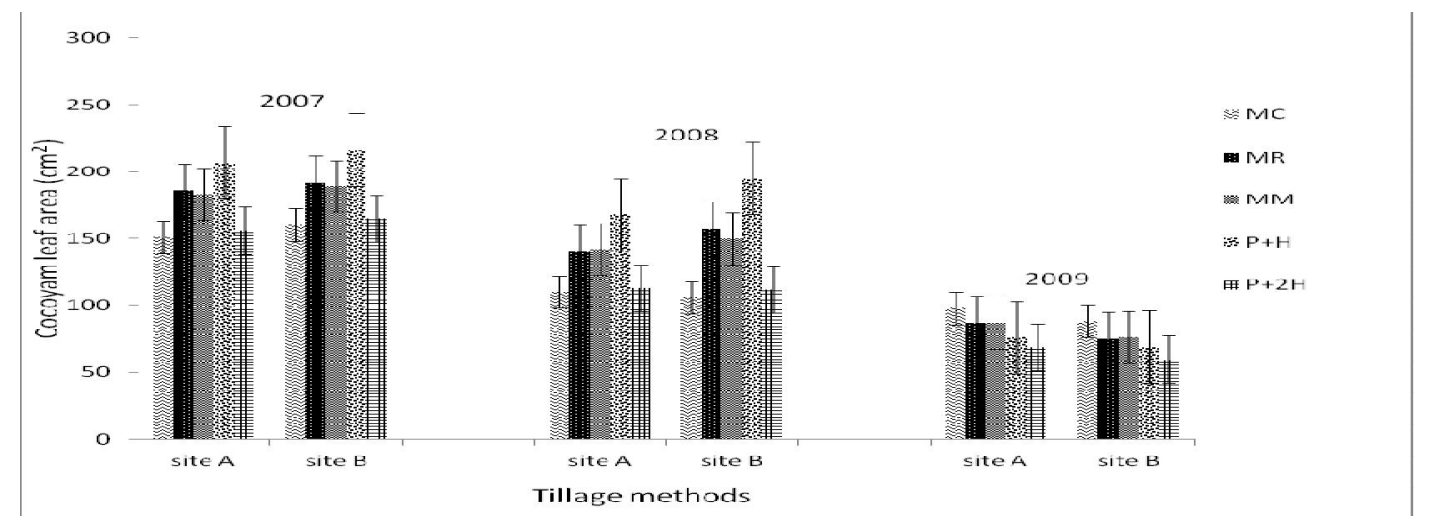

Figure 2: Effect of tillage methods on cocoyam leaf area in 2007, 2008 and 2009. Vertical bars show standard errors of paired comparisons.

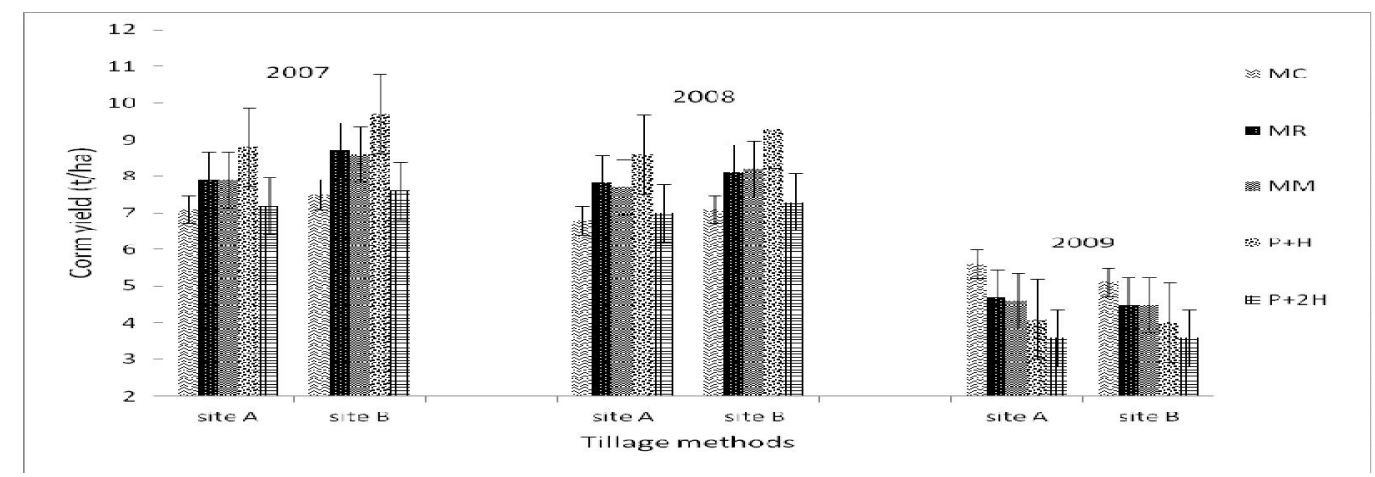

Figure 3: Effect of tillage methods on corm yield of cocoyam in 2007, 2008 and 2009. Vertical bars show standard errors of paired comparisons. 
Effect of poultry manure on the growth and corm yield of cocoyam

Figures 4, 5 and 6, respectively show the result of the effect of poultry manure on plant height, leaf area and corm yield of cocoyam in 2007, 2008 and 2009. Irrespective of tillage treatment, plant height, leaf area and corm yield increased with level of poultry manure up to $7.5 \mathrm{t} / \mathrm{ha}$. After this level the parameters reduced. This observation applies to both sites. This finding is consistent with the finding that this level of poultry gave highest values of leaf $\mathrm{K}, \mathrm{Ca}$ and $\mathrm{Mg}$. This suggested that these nutrients dictated the growth and yield of cocoyam.

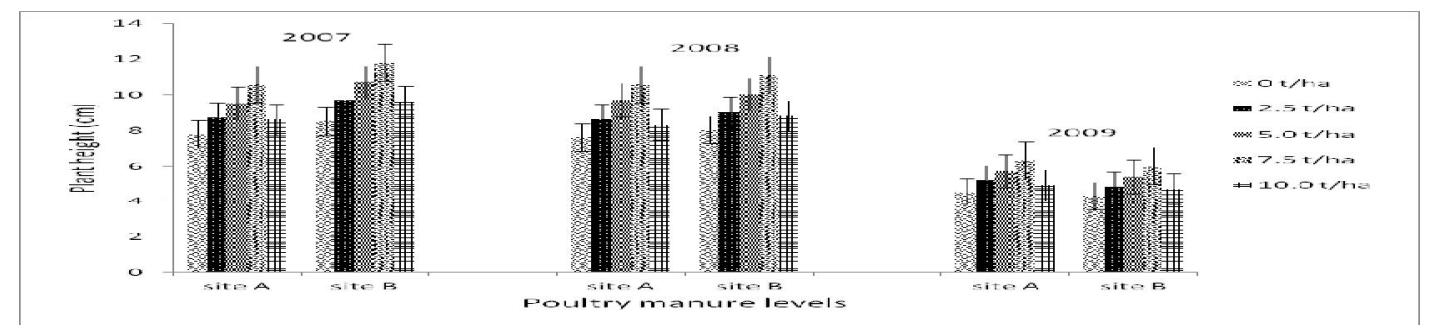

Figure 4: Effect of poultry manure levels on cocoyam plant height in 2007, 2008 and 2009. Vertical bars show standard errors of paired comparisons.

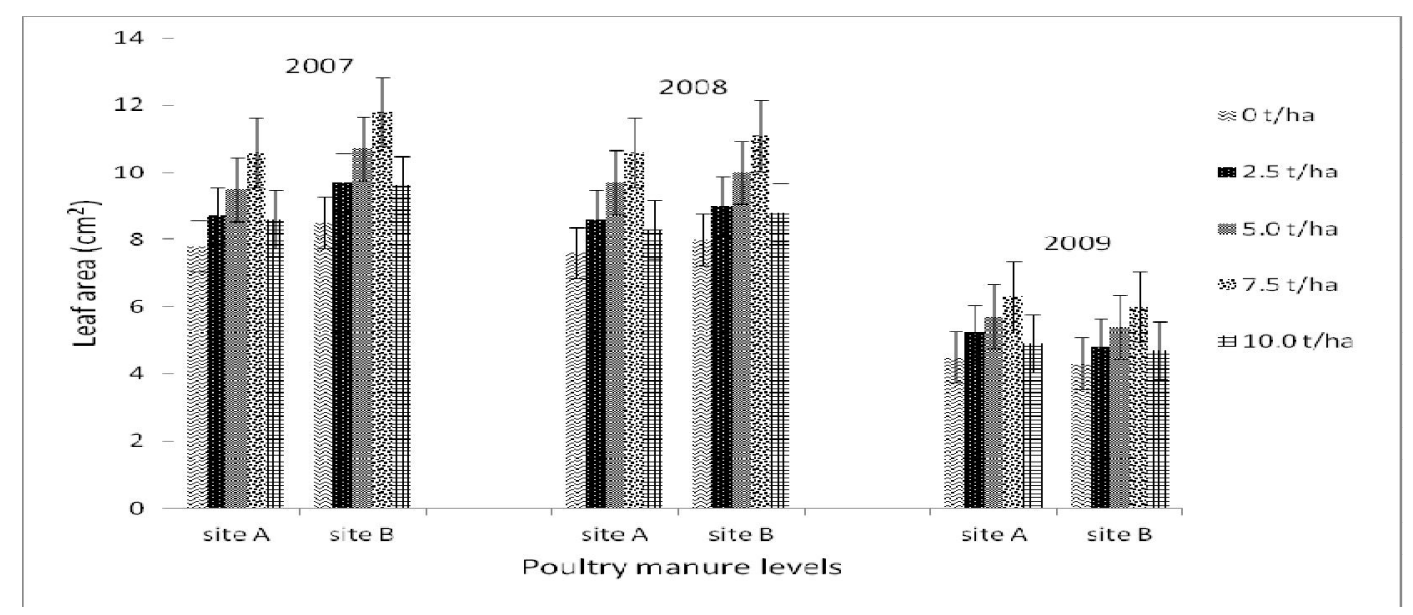

Figure 5. Effect of poultry manure level on cocoyam leaf area in 2007, 2008 and 2009. Vertical bars show standard errors of paired comparisons.
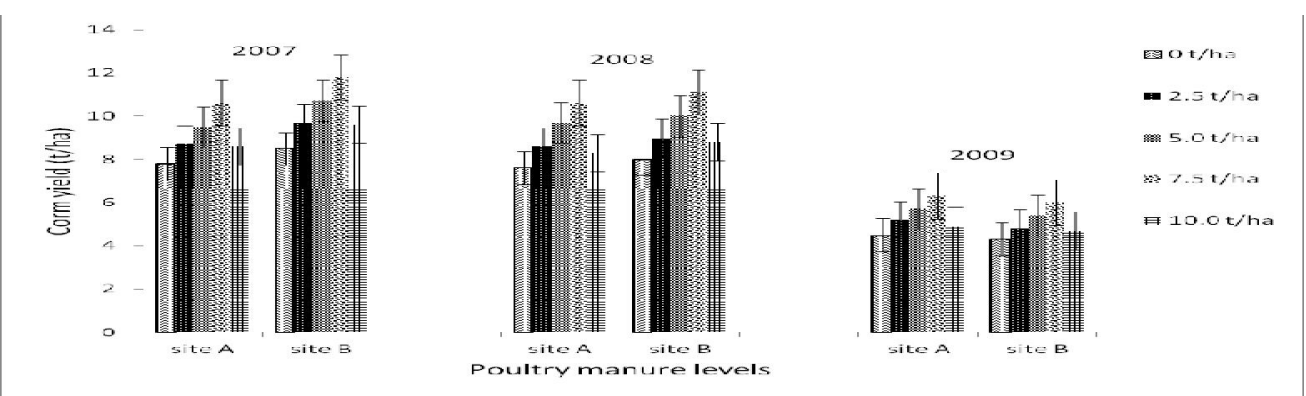

Figure 6: Effect of poultry manure on corm yield of cocoyam in 2007, 2008 and 2009. Vertical bars show standard errors of paired comparisons. 


\section{Growth and Corm Yield of Cocoyam}

\section{Effect of tillage and poultry manure on the growth and corm yield of cocoyam}

Table 4 shows the mean of the combination of tillage methods and levels of poultry manure on the growth and corm yield of cocoyam in 2007, 2008 and 2009. In 2007 and 2008, the P+H+7.5PM gave the highest values of plant height, leaf area and corm yield. However, in 2009 the MC+7.5PM gave highest value. Generally the unmanured $\mathrm{MC}, \mathrm{P}+\mathrm{H}$ and $\mathrm{P}+2 \mathrm{H}$ had least values of the parameters. The mean data for the three years show that the $\mathrm{P}+\mathrm{H}+7.5 \mathrm{PM}$ had highest value of corm yield $(10.2 \mathrm{t} / \mathrm{ha})$, while the unmanured $\mathrm{P}+2 \mathrm{H}$ had least value of $6.1 \mathrm{t} / \mathrm{ha}$. Relative to $\mathrm{P}+2 \mathrm{H}$, the $\mathrm{P}+\mathrm{H}+7.5 \mathrm{PM}$ increased corm yield by $69 \%$. Therefore in order to maximise performance of cocoyam, combination of conventional tillage with poultry manure at $7.5 \mathrm{t} / \mathrm{ha}$ is recommended.

The superior effect of $\mathrm{P}+\mathrm{H}+7.5 \mathrm{PM}$ can be adduced to combination of attributes of lower soil density (adduced to reduced tillage) and maximum availability of nutrients especially as organic matter, $\mathrm{N}, \mathrm{P}$ and $\mathrm{K}$ are concerned. Tuber crops such as yam and sweet potato are sensitive to raised soil bulk density which reduces their tuber expansion (Agbede, 2006; Agbede and Adekiya, 2009). Hence they require reduce tillage (Adekiya and Ojeniyi, 2011). Yield and nutrients content of tuber crops such as cassava, yam and sweet potato were found to improve significantly in response to application of poultry manure (Odedina et al., 2010; Adeleye et al., 2010; Lawal et al., 2010). The manure is an effective source of nutrients to crops and had balanced nutritional and residual effect compared with chemical fertilizer (Ayeni et al., 2010; Akanni and Ojeniyi, 2007). Poultry manure also improves physical properties and has mulching effect (Akanni and Ojeniyi, 2007).

Table 4. Mean values of Growth and Yield Parameters for the three years of the experiment from the two sites

\begin{tabular}{llll}
\hline Treatment & $\begin{array}{l}\text { Plant height } \\
(\mathrm{cm})\end{array}$ & $\begin{array}{l}\text { Leaf area } \\
\left(\mathrm{cm}^{2}\right)\end{array}$ & $\begin{array}{l}\text { Corm yield } \\
(\mathrm{t} / \mathrm{ha})\end{array}$ \\
\hline MCO & $53.5 \mathrm{hi}$ & $120.7 \mathrm{jk}$ & $6.5 \mathrm{hi}$ \\
MC+2.5PM & $60.3 \mathrm{fg}$ & $135.5 \mathrm{hi}$ & $7.5 \mathrm{fg}$ \\
MC+5.0PM & $67.7 \mathrm{de}$ & $156.0 \mathrm{fg}$ & $8.3 \mathrm{de}$ \\
MC+7.5PM & $76.5 \mathrm{bc}$ & $179.8 \mathrm{~cd}$ & $9.3 \mathrm{bc}$ \\
MC+10.0PM & $60.8 \mathrm{fg}$ & $140.5 \mathrm{hi}$ & $7.3 \mathrm{fg}$ \\
MRO & $57.8 \mathrm{gh}$ & $139.5 \mathrm{hi}$ & $7.0 \mathrm{gh}$ \\
MR+2.5PM & $64.0 \mathrm{ef}$ & $159.0 \mathrm{fg}$ & $7.8 \mathrm{ef}$ \\
MR+5.0PM & $70.7 \mathrm{~cd}$ & $179.0 \mathrm{~cd}$ & $8.6 \mathrm{~cd}$ \\
MR+7.5PM & $81.3 \mathrm{ab}$ & $206.2 \mathrm{ab}$ & $9.5 \mathrm{ab}$ \\
MR+10.0PM & $64.5 \mathrm{e}$ & $162.8 \mathrm{ef}$ & $7.7 \mathrm{ef}$ \\
MMO & $57.9 \mathrm{gh}$ & $137.8 \mathrm{hi}$ & $6.9 \mathrm{hi}$ \\
MM+2.5PM & $63.8 \mathrm{ef}$ & $159.0 \mathrm{fg}$ & $7.8 \mathrm{ef}$ \\
MM+5.0PM & $72.3 \mathrm{~cd}$ & $177.8 \mathrm{de}$ & $8.7 \mathrm{~cd}$ \\
MM+7.5PM & $81.0 \mathrm{ab}$ & $206.5 \mathrm{ab}$ & $9.6 \mathrm{ab}$ \\
MM+10.0PM & $65.2 \mathrm{ef}$ & $163.7 \mathrm{de}$ & $7.6 \mathrm{fg}$ \\
P+HO & $63.2 \mathrm{fg}$ & $156.2 \mathrm{gh}$ & $7.4 \mathrm{gh}$ \\
P+H+2.5PM & $72.0 \mathrm{~cd}$ & $176.3 \mathrm{de}$ & $8.4 \mathrm{de}$ \\
P+H+5.0PM & $79.2 \mathrm{~b}$ & $201.5 \mathrm{bc}$ & $9.3 \mathrm{bc}$ \\
P+H+7.5PM & $89.0 \mathrm{a}$ & $224.7 \mathrm{a}$ & $10.2 \mathrm{a}$ \\
P+H+10.0PM & $72.0 \mathrm{~cd}$ & $179.8 \mathrm{~cd}$ & $8.0 \mathrm{de}$ \\
P+2HO & $49.0 \mathrm{i}$ & $112.5 \mathrm{k}$ & $6.1 \mathrm{i}$ \\
P+2H+2.5PM & $54.7 \mathrm{~h}$ & $130.0 \mathrm{ij}$ & $6.9 \mathrm{hi}$ \\
P+2H+5.0PM & $60.5 \mathrm{de}$ & $148.0 \mathrm{gh}$ & $7.7 \mathrm{ef}$ \\
P+2H+7.5PM & $69.5 \mathrm{de}$ & $171.6 \mathrm{de}$ & $8.5 \mathrm{~cd}$ \\
P+2H+10.0PM & $55.5 \mathrm{gh}$ & $132.8 \mathrm{ij}$ & $6.7 \mathrm{hi}$ \\
\hline
\end{tabular}


Adekiya, O.A. et al

Values followed by similar letters under the same column are not significantly different at $p=0.05$ according to Duncan's multiple range test (DMRT). MC: manual clearing; MR: manual ridging; MM: manual mounding; $P+H$ : ploughing + harrowing; P+2H: ploughing + harrowing twice; PM: poultry manure.

\section{CONCLUSION}

For maximum soil and cocoyam productivity, the combination of conventional tillage $(\mathrm{P}+\mathrm{H})$ with 7.5 t/ha poultry manure is recommended

\section{REFERENCES}

Adekiya, A.O. (2014). Response of soil properties and cocoyam (Xanthosoma sagittifolium) to tillage and poultry manure on Alfisol of Owo southwest Nigeria. Unpublished Ph.D Thesis, Department of Crop, Soil and Pest Management, Federal University of Technology, Akure. 250pp.

Adekiya, A.O. and Ojeniyi, S.O. (2011) Soil physical properties and cocoyam performance as influenced by tillage on an Alfisol in southwest Nigeria. Nigerian Journal of Soil Science 21 (1), $16-21$.

Adekiya, A.O. and Agbede, T.M. (2009). Growth and yield of tomato (Lycopersicon esculentum Mill) as influenced by poultry manure and NPK fertilizer. Emirate Journal of Food and Agriculture. 21(1), 10-20.

Adeleye, E.O., Ayeni, L.S. and Ojeniyi, S.O. (2010). Effect of poultry manure on soil physicochemical properties and leaf nutrient contents and yield of yam on an Alfisol in southwest Nigeria. Journal of American Science. 6 (10), 871-878.

Agbede, T.M. (2006). Effect of tillage on soil properties and yam yield on an Alfisol in southwestern Nigeria. Soil Tillage Research 86, 1-6.

Agbede, T.M.(2008). Nutrient availability and cocoyam yield under different tillage practices. Soil Tillage Research 99, 49-57.

Agbede, T.M. and Adekiya, A.O. (2009).Tillage effects on soil properties and performance of sweet potato on Alfisol in southwest Nigeria. American-Eurasian Journal of Sustainable Agriculture 3(3), 561-568.

Agbede, T.M. and Ojeniyi, S.O. (2003). Effect of land preparation methods on soil properties and yield of yam grown on Alfisols. Nigerian Journal of Soil Science 13, 68-75.

Akanni, D.I. and Ojeniyi, S.O. (2007) Effect of different levels of poultry manure on soil physical properties, nutrient status, growth and yield of tomato. Research Journal of Agronomy $1,1-4$.

Akinrinde, E.A. and Obigbesan, G. O. (2000). Evaluation of the fertility status of selected soils for crop production in five ecological zones of Nigeria. Proceedings of the 26th Annual Conference of Soil Science Society of Nigeria, Ibadan, Nigeria, pp. 279-288. 


\section{Growth and Corm Yield of Cocoyam}

AOAC. (1997). Official Methods of Analysis of the Association of Official Analytical Chemists International, 16th Edition, Vol. 972. AOAC International, Arlington, VA., pp.43.

Ayeni, L.S., Adetunji, M.T., Ojeniyi, S.O., Ewulo, B.S. and Adeyemo, A.J. (2008). Comparative and cumulative effect of cocoa pod husk ash and poultry manure on soil and maize nutrient contents and yield. American-Eurasian Journal of Sustainable Agriculture 2 (1), 92 - 97.

Bradbury, J.H. (1988). Chemical composition of tropical root crops. ASEAN Food Journal 4, 313.

Bremner, J.M. (1996). Nitrogen-total. In: Sparks, D.I. (Ed.). Methods of Soil Analysis. Part 3. Chemical Methods. 2nd Edition. SSSA Book Series No. 5. ASA and SSSA, Madison, WI, USA, pp. 1085-1121.

Carter, M.R. (1993). Soil Sampling and Methods of Analysis. Canadian Society of Soil Science, Lewis Publishers, London, 823pp.

Davies, E.M., Labuschagne, M.T., Koen, E., Benesi, I.R.M. and Saka, J.D.K. (2008). Some properties of starches from cocoyam in Malawi. African Journal of Food Science 2, 102-111.

Eghball, B. (2002). Soil properties as influenced by phosphorus and nitrogen based manure and compost applications. Agronomy Journal 94, 128-135.

FAO (1998). World resources base for soil resources world. Soil Resources Report 84. Food and Agriculture Organisation of the United Nations, Rome.

FAO (1991) Production year book. FAO, Rome.

Frank, K., Beegle, D., Denning, J. (1998). Phosphorus. In: Brown, J.R. (Ed.), Recommended Chemical Soil Test Procedures for the North Central Region, North Central Regional Research Publication No. 221 (revised ) Missouri Agric. Exp. Stn., Columbia, MO, pp. 21-26.

Hulugalle, N.R., Lal, R. and Opara-Nadi, O.A. (1985). Effect of tillage system and mulch on soil properties and growth of yam (Dioscorea rotundata) and cocoyam (Xanthosoma sagittifolium) on an Ultisol. Journal of Root Crops 11, 9-12.

Kay, D.E. (1987). Crop and product digest No. 2 root crops. 2nd Edition, Tropical Development and Research Institute, London, 380pp.

Lawal, I.O., Adeoye, G.O., Asiedu, R. and Ojeniyi, S.O. (2010).Organomineral fertilizer effects on yield and nutrient uptake of white yam in Ibadan, southwest Nigeria. Nigerian Journal of Soil Science 20 (2), 35-41.

Ndaeyo, N.U., Ekpe, E.O., Edem, S.O. and Umoh, U.G. (2003). Growth and yield responses of Colocasia esculenta and Xanthosoma sagittifolium to tillage practices in Uyo, southeastern Nigeria. Indian Journal of Agric. Sci. 73, 194-198.

Ndon, B.A., Ndulaka, N. H.and Ndaeyo, N. U. (2003). Stabilization of yield parameters and some nutrients components in cocoyam cultivars with time in Uyo, southeastern Nigeria. Global J. Agric. Sci. 2(2), 74-78. 


\section{Adekiya, O.A. et al}

Nelson, D.W. and Sommers, L.E. (1992). Total carbon, organic carbon and organic matter. In: Page, A. L., Miller, R.H. and Keeney; D.R. (Eds.). Methods of Soil Analysis. Part 2. ASA, Madison, WI, USA, pp. 539-580.

Nyakatawa, E.Z., Reddy, K.C. and Sistani, K.R. (2001). Tillage, cover cropping and poultry litter effects on soil chemical properties. Soil Tillage Research 58, 69-79.

Obi, M.E. and Akinsola, A. O. (1995). The effect of lime application on the yield of tomato and chemical properties of an Iwo soil in southwestern Nigeria. Nigerian Journal of Soil Science 11, 77-78.

Onayemi, O. and Nwigwe, N.C. (1987). The effect of processing on oxalate content of cocoyam. Lebensmittel-Wissenschaftand Technologie 20, 293-295.

Onwueme, T.C. (1991). An analysis of the constraints in the delivery systems for tropical root and tuber crops. Tropical root crop in a developing economy. In: Proceedings of the 9th Symposium of International Society of Tropical Root Crops (ISTRC), Accra, Ghana, pp.52-53.

Odedina, J.N., Ojeniyi, S.O. and Odedina, S.A. (2010). Comparative effect of animal manures on soil nutrient status and performance of cassava. Nigerian Journal of Soil Science 21 (1), 58-63.

Sefa-Dedeh, S. and Kofi-Agyir, S.E.(2002). Starch structure and some properties of cocoyam (Xanthosoma sagittifolium and Colocacia esculentum) starch and raphides. Food Chemistry 79, 435-444.

Sheldrick, B. and Hand Wang. C. (1993). Particle-size distribution. In: Carter, M.R. (Ed.), Soil Sampling and Methods of Analysis. Canadian Society of Soil Science, Lewis Publishers, Ann Arbor, MI, pp. 499-511.

Tel, D.A. and Hagarty, M. (1984). Soil and Plant Analysis. IITA/University of Guelph. 277pp. 